\title{
New host records for Amblyomma rotundatum (Acari: Ixodidae) from Grussaí restinga, Rio de Janeiro, Brazil
}

\author{
Novos registros de hospedeiros para Amblyomma rotundatum (Acari: Ixodidae) \\ da restinga de Grussaí, Rio de Janeiro, Brasil \\ Lúcio André Viana ${ }^{1 *}$; Gisele Regina Winck ${ }^{1}$; Marlon Almeida-Santos ${ }^{1}$; Felipe Bottona da Silva Telles ${ }^{1}$; \\ Gilberto Salles Gazêta² ${ }^{2}$ Carlos Frederico Duarte Rocha ${ }^{1}$
}

\begin{abstract}
${ }^{1}$ Laboratório de Ecologia de Vertebrados, Departamento de Ecologia, Universidade do Estado do Rio de Janeiro - UERJ, Rio de Janeiro, RJ, Brasil

${ }^{2}$ Laboratório de Referência Nacional em Vetores das Riquetsioses - LIRN, Instituto Oswaldo Cruz - FIOCRUZ, Rio de Janeiro, RJ, Brasil
\end{abstract}

Received September 27, 2012

Accepted June 11, 2012

\begin{abstract}
Amblyomma rotundatum Koch is a parthenogenetic tick usually associated with reptiles and amphibians. However, relatively few studies on occurrences of ticks in wild reptile populations in Brazil have been produced. The aim of this study was to analyze the presence of ticks associated with reptile species in the Grussaí restinga, in the municipality of São João da Barra, state of Rio de Janeiro, Brazil. Between December 2010 and January 2011, 131 individuals belonging to nine species of reptiles of the order Squamata were sampled: the lizards Tropidurus torquatus $(\mathrm{n}=51)$, Hemidactylus mabouia $(\mathrm{n}=25)$, Mabuya agilis $(\mathrm{n}=30)$, Mabuya macrorhyncha $(\mathrm{n}=6)$, Cnemidophorus littoralis $(\mathrm{n}=5)$ and Ameiva ameiva $(\mathrm{n}=10)$; and the snakes Philodryas olfersii $(\mathrm{n}=2)$, Oxyrhopus rhombifer $(\mathrm{n}=1)$ and Micrurus corallinus $(\mathrm{n}=1)$. The only tick species found to be associated with any of the reptiles sampled was $A$. rotundatum. One adult female was detected on one individual of the lizard $A$. ameiva, one nymph on one individual of the lizard T. torquatus and four nymphs on one individual of the snake $P$. olfersii. This study is the first record of parasitism of $A$. rotundatum involving the reptiles T. torquatus and $P$. olfersii as hosts. Our results suggest that in the Grussaí restinga habitat, $A$. rotundatum may use different species of reptiles to complete its life cycle.
\end{abstract}

Keywords: Ectoparasites, ticks, reptiles, lizards, snakes, Amblyomma rotundatum.

\section{Resumo}

Amblyomma rotundatum Koch é um carrapato partenogenético geralmente associado a répteis e anfíbios. Entretanto existem relativamente poucos estudos sobre a ocorrência de carrapatos em populaçôes silvestres de répteis no Brasil. $\mathrm{O}$ objetivo deste estudo foi analisar a presença de carrapatos associados às espécies de répteis em uma comunidade na restinga de Grussaí, município de São João da Barra, Estado do Rio de Janeiro, Brasil. Foram amostradas, entre os meses de dezembro de 2010 e janeiro de 2011, 131 indivíduos pertencentes a nove espécies de répteis da ordem Squamata: lagartos Tropidurus torquatus $(\mathrm{n}=51)$; Hemidactylus mabonia $(\mathrm{n}=25)$, Mabuya agilis $(\mathrm{n}=30)$, Mabuya macrorhyncha $(\mathrm{n}=6)$, Cnemidophorus littoralis $(\mathrm{n}=5)$ e Ameiva ameiva $(\mathrm{n}=10)$, e serpentes Philodryas olfersii $(\mathrm{n}=2)$, Oxyrhopus rhombifer $(\mathrm{n}=1)$ e Micrurus corallinus $(\mathrm{n}=1)$. A única espécie de carrapato encontrada associada a espécimes de répteis foi $A$. rotundatum, tendo sido encontrada uma fêmea adulta em um indivíduo do lagarto $A$. ameiva, uma ninfa em um T. torquatus e quatro ninfas em uma serpente $P$. olfersii. O presente estudo constitui o primeiro registro do parasitismo de $A$. rotundatum nos répteis $T$. torquatus e $P$. olfersii como hospedeiros. Nossos resultados sugerem que no habitat da restinga de Grussaí, $A$. rotundatum pode utilizar diferentes espécies de répteis para a realização do seu ciclo de vida.

Palavras-chave: Ectoparasitas, carrapatos, répteis, lagartos, serpentes, Amblyomma rotundatum.

\footnotetext{
*Corresponding author: Lúcio André Viana

Laboratório de Ecologia de Vertebrados, Departamento de Ecologia,

Universidade do Estado do Rio de Janeiro - UERJ, Rua São Francisco Xavier,

524, Maracanã, CEP 20550-019, Rio de Janeiro, RJ, Brasil

e-mail: lucviana74@gmail.com
} 
Amblyomma rotundatum Koch is a parthenogenetic tick (ARAGÃO, 1912; OBA; SCHUMAKER, 1983) commonly associated with species of reptiles and amphibians (DURDEN; KNAPP, 2005; PONTES et al., 2009; GUGLIELMONE; NAVA, 2010). Experimental studies have shown that during its life cycle, this species uses two or three different host species (OBA; SCHUMAKER, 1983; RODRIGUES et al., 2010). In addition, ticks can act as vectors of hemoparasites of the genera Hemolivia and Hepatozoon for frogs (PETIT et al., 1990; LAINSON et al., 2007), lizards (SMALLRIDGE; PAPERNA, 1997; PAPERNA et al., 2002) and turtles (PAPERNA, 2006; SIROKÝ et al., 2009).

In Brazil, except for the broad study by Pontes et al. (2009) involving ticks associated with a community of snakes in the Atlantic Forest, most studies have been limited to recording parasitism of reptiles by ticks in random samples, usually restricted to a few individual specimens (LABRUNA et al., 2002, 2005; DANTAS-TORRES et al., 2005, 2008; MARTINS et al., 2007; LOPES et al., 2010), studies involving captive hosts (see review in GUGLIELMONE; NAVA, 2010), or characterization of the life cycle of ticks Amblyomma dissimile or A. rotundatum under experimental conditions (ARAGÃO, 1912; OBA; SCHUMAKER 1983; FREITAS et al., 2004; RODRIGUES et al., 2010).

Current knowledge concerning infestation by Amblyomma in wild reptiles is still limited, and thus, the present study makes a contribution through recording parasitism by the tick $A$. rotundatum on reptiles in a restinga habitat, the Grussaí restinga, in the northern region of the state of Rio de Janeiro.

The study was conducted during December 2010 and January 2011, in a restinga remnant in the municipality of São João da

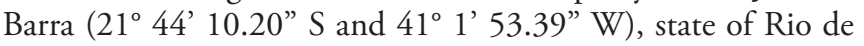
Janeiro, Brazil. Restingas are habitats consisting of dunes and sandy plains covered with xerophytic herbaceous vegetation and shrubs that occur along the coast of Brazil (EITEN, 1992). The climate is tropical subhumid and semi-arid, with a mean annual rainfall ranging from 800 to $1,200 \mathrm{~mm}$ and higher incidence of rainfall during the summer months and lower in winter (BRASIL, 1983).

The lizards were caught with the aid of compressed air rifles, while the snakes were caught manually. Animals that were still alive were euthanized by means of ethyl ether inhalation and were carefully examined for the presence of ticks on every part of the body.

All the ticks detected were collected manually or with forceps, stored in alcohol $\left(70^{\circ} \mathrm{GL}\right)$, identified and deposited in the collection of the National Reference Laboratory of Vectors of Rickettsial diseases, FIOCRUZ, under access numbers Ixo 1482, Ixo 1483 and Ixo 1484, for the specimens collected from Philodryas olfersii, Ameiva ameiva and Tropidurus torquatus, respectively. The keys developed by Aragão and Fonseca (1961) and Martins et al. (2010) were used to identify adults and nymphs, respectively.

A total of 131 individual specimens from nine reptiles species were sampled (Table 1). The only tick species identified was A. rotundatum, at low intensities. One adult female was found on the ventral region of the lizard $A$. ameiva (frequency $=10 \%$, $\mathrm{n}=10$ ) (Figure $1 \mathrm{~b}$ ) and one nymph on the lizard T. torquatus (frequency $=2 \%, n=51$ ). Four nymphs was detected on one specimen of the snake $P$. olfersii (established under its scales), corresponding to a frequency of $50 \%$, although this value was based on only two individuals of this snake species (Figure 1a, Table 1).
Table 1. Parasitism of different species of reptiles by the tick Amblyomma rotundatum in the Grussaí restinga, state of Rio de Janeiro, Brazil.

\begin{tabular}{cccc}
\hline Host & No (hosts) & Positive & Intensity* $^{*}$ \\
\hline Lizards & & & \\
Tropidurus torquatus & 51 & 1 & $1 \mathrm{~N}$ \\
Mabuya agilis & 29 & 0 & 0 \\
Hemidactylus mabouia & 25 & 0 & 0 \\
Ameiva ameiva & 10 & 1 & $1 \mathrm{~F}$ \\
Mabuya macrorhyncha & 7 & 0 & 0 \\
Cnemidophorus littoralis & 5 & 0 & 0 \\
Snakes & & & \\
Philodryas olfersii & 2 & 1 & $4 \mathrm{~N}$ \\
Micrurus corallinus & 1 & 0 & 0 \\
Oxyrhopus rhombifer & 1 & 0 & 0 \\
Total & 131 & 3 & 5 \\
\hline
\end{tabular}

${ }^{*} \mathrm{~F}=$ female, $\mathrm{N}=$ nymph, $\mathrm{N}^{\circ}=$ number.

Although the tick $A$. rotundatum is considered to be a common species on ectothermic vertebrates (GUGLIELMONE; NAVA, 2010), the present study is the first formal scientific record of this tick species parasitizing the reptiles T. torquatus and $P$. olfersii. Analysis on the data obtained indicated that the frequency and intensity of infestation by $A$. rotundatum in this community of reptiles sampled in the Grussaí restinga habitat was low. The only previous information available regarding infestation by A. rotundatum in a community of reptiles in nature comes from the study by Pontes et al. (2009), who reported comparatively higher frequency and intensity of infestation in a community of snakes in an area of dense tropical rainforest in the Atlantic Forest located in Serra do Mendanha in the state of Rio de Janeiro. The scarcity of knowledge concerning $A$. rotundatum infestation on reptiles in nature makes it difficult to determine to what extent the differences in frequency and intensity observed are due to differences in the types of environments studied (rainforest and restingas).

The only information regarding infestation by ticks of the genus Amblyomma on A. ameiva is in relation to identification of A. dissimile in Venezuela (DIAZ-UNGRIA, 1957) and in Trinidad and Tobago (AITKEN et al., 1968). Recently, A. dissimile was also recorded infesting an individual of $A$. ameiva in the state of Maranhão, Brazil (LOPES et al., 2010). Amblyomma rotundatum has been reported on $A$. ameiva, but without location information (ONOFRIO, 2007). Lainson et al. (2007) demonstrated the vector function of $A$. rotundatum in relation to transmission of the protozoan hemoparasite Hemolivia stellata between the anuran Rhinella marina and the lizard A. ameiva.

Previous records of $A$. rotundatum parasitizing T. torquatus are restricted to the use of this and other species of reptiles under experimental conditions, to study the biological cycle of the tick (ARAGÃO, 1912; FREITAS et al., 2004). Labruna et al. (2005) reported an occurrence of a male $A$. rotundatum in the Amazon region parasitizing Tropidurus sp., probably $T$. oreadicus, since T. torquatus does not occur in the region (SENA et al., 2008). In the state of Pernambuco, northeastern Brazil, a lizard of the genus Tropidurus parasitized by two nymphs of Amblyomma sp. was recorded in the Dois Irmãos State Park (DANTAS-TORRES et al., 2010), and also an individual of T. hispidus infested by three nymphs 

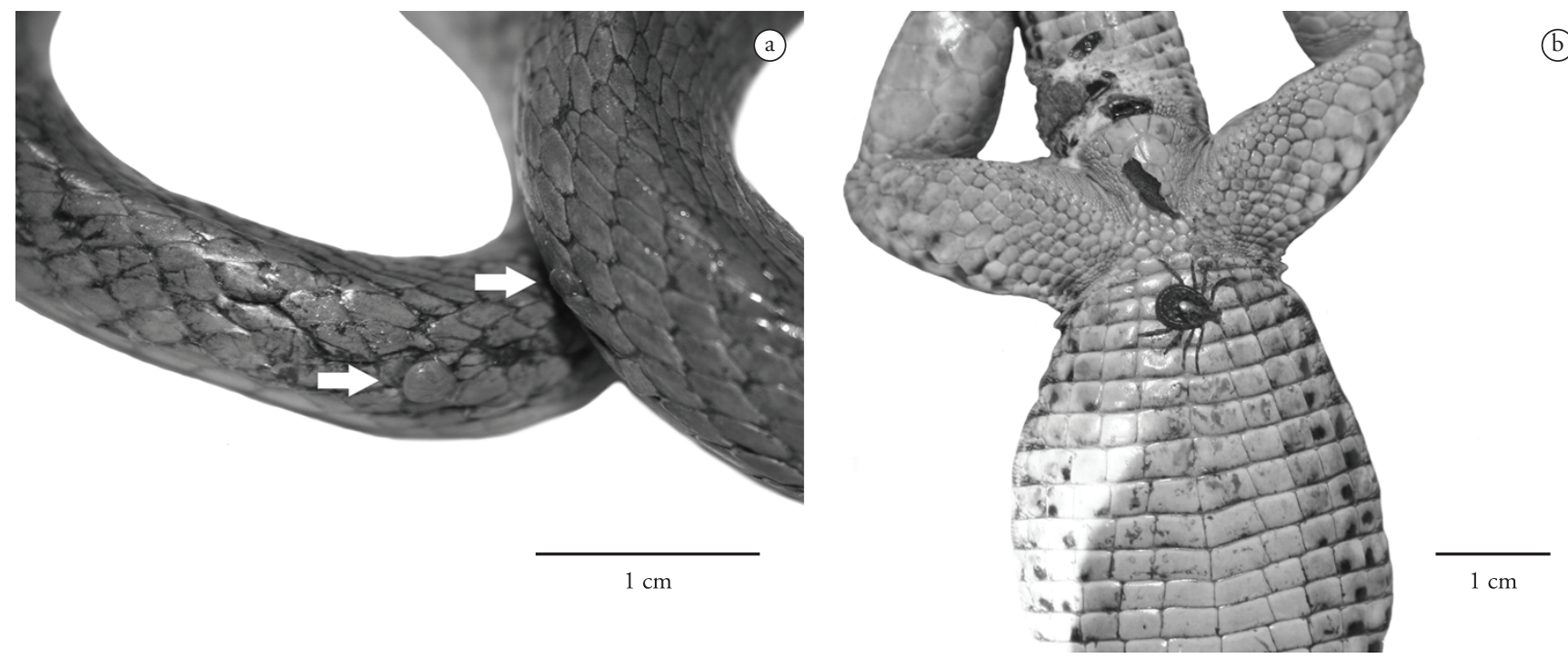

Figure 1. Amblyomma rotundatum ticks detected on reptiles in the Grussaí restinga, Campos dos Goytacazes, state of Rio de Janeiro, Brazil. a) Nymphs (arrows) under the scales of the colubrid snake Philodryas olfersii; b) female adult (arrow) on the lizard Ameiva ameiva.

of $A$. dissimile (DANTAS-TORRES et al., 2008). Tropidurus hispidus was also found infested by Amblyomma sp. in Venezuela (PRIETO, 1980).

The only record of parasitism by ticks on the snake $P$. olfersii was reported by Lizaso (1984). This author observed infestation by Amblyomma sp. during fauna rescue at the Água Vermelha hydroelectric plant, on the borders of the states of São Paulo and Minas Gerais, Brazil. During a study to determine occurrences of ticks on snakes in the Serra do Mendanha, state of Rio de Janeiro, two individuals of $P$. olfersii were found to be negative for the presence of ticks (PONTES et al., 2009). However, in the same study, individuals of the sympatric snakes Chironius laevicollis, Spilotes pullatus and Xenodon neuwiedii presented infestation by A. rotundatum. Dantas-Torres et al. (2010) reported parasitism of a snake of the genus Philodryas by a nymph of Amblyomma sp. collected in the Dois Irmãos State Park in the state of Pernambuco.

In conclusion, this study extends the list of reptilian hosts for the tick $A$. rotundatum. Analysis of the results obtained suggests that in the Grussaí restinga habitat, $A$. rotundatum uses different species of reptiles to complete its life cycle. Considering the biological capacity of $A$. rotundatum to transmit blood-borne protozoa to reptiles and amphibians, and the previous findings of natural infection by Rickettsia bellii in the state of Rondonia (LABRUNA et al., 2004), additional studies in the Grussaí restinga could provide an important opportunity to elucidate the parasite ecology of the wildlife community in this region.

\section{Acknowledgements}

This study was supported by grants from the Fundação Carlos Chagas Filho de Amparo a Pesquisa do Estado do Rio de Janeiro (FAPERJ) to LAV (procedural no. E-26/102.498/2010), to GRW (E-26/100.769/2008 and E-26/100.477/2011), and CNPq to CFDR (304791/2010-5 and 470265/2010-8). This study was approved by the Instituto Brasileiro do Meio Ambiente e dos Recursos Naturais Renováveis (IBAMA), Brazilian Ministry of the Environment (authorization no. 15322-2).

\section{References}

Aitken THG, Worth CB, Tikasingh ES. Arbovirus studies in Bush Bush Forest, Trinidad, W. I., September 1959 - December 1964. III. Entomologic Studies. Am J Trop Med Hyg 1968; 17(2): 253-268. PMid:4384665.

Aragão HB. Contribuição para a sistemática e biolojia dos ixódidas: Partenojeneze em carrapatos. Mem Inst Oswaldo Cruz 1912; 4(1): 96-119.

Aragão HB, Fonseca F. Notas de Ixodologia. VIII. Lista e chave para os representantes da fauna ixodológica brasileira. Mem Inst Oswaldo Cruz 1961; 59(2): 115-130. PMid:13861962.

Brasil. Ministério das Minas e Energia. Secretária Geral. Projeto RADAMBRASIL. Rio de Janeiro/Vitória; Geologia, Geomorfologia, Pedologia, Vegetação e Uso Potencial da Terra. Rio de Janeiro: Ministério das Minas e Energia; 1983. 780 p. Folha SF. 23/24.

Dantas-Torres F, Ferreira DR, Melo LM, Lima PA, Siqueira DB, Rameh-de-Albuquerque LC, et al. Ticks on captive and free-living wild animals in northeastern Brazil. Exp Appl Acarol 2010; 50(2): 181-189. http://dx.doi.org/10.1007/s10493-009-9296-5

Dantas-Torres F, Oliveira-Filho EF, Soares FA, Souza BO, Valença RB, Sá FB. Ticks infesting amphibians and reptiles in Pernambuco, Northeastern Brazil. Rev Bras Parasitol Vet 2008; 17(4): 218-221. PMid:19265581.

Dantas-Torres F, Oliveira-Filho EF, Souza BOF, Sá FB. First Record of Amblyomma rotundatum Koch, 1844 (Acari: Ixodidae) parasitizing Crotalus durissus cascavella (Wagler, 1824) (Squamata: Viperidae) in the state of Pernambuco, Brazil. Arq Inst Biol 2005; 72(3): 389-390.

Diaz-Ungria C. Nota sobre las espécies de acarina de Venezuela. Rev Sanidad Asist Soc 1957; 22(5): 457-467.

Durden LA, Knapp CR. Ticks parasitizing reptiles in the Bahamas. Med Vet Entomol 2005; 19(3): 326-328. http://dx.doi.org/10.1111/ j.1365-2915.2005.00567.x

Eiten G. Natural Brazilian vegetation types and their causes. An Acad Bras Ciênc 1992; 64(S1): 35-65. 
Freitas LHT, Faccini JLH, Daemon E, Prata MCA, Barros-Battesti DM. Experimental infestation with the immatures of Amblyomma dissimile Koch, 1844 (Acari: Ixodidae) on Tropidurus torquatus (Lacertilia: Iguanidae) and Oryctolagus cuniculus. Arq Bras Med Vet Zootec 2004; 56(1): 126-129. http://dx.doi.org/10.1590/ S0102-09352004000100021

Guglielmone AA, Nava S. Hosts of Amblyomma dissimile Koch, 1844 and Amblyomma rotundatum Koch, 1844 (Acari: Ixodidae). Zootaxa 2010; 2541: 27-49.

Labruna MB, Paula CD, Lima TF, Sana DA. Ticks (Acari: Ixodidae) on wild animals from the Porto Primavera Hydroelectric power station area, Brazil. Mem Inst Oswaldo Cruz 2002; 97(8): 1133-1136. http://dx.doi. org/10.1590/S0074-02762002000800012

Labruna MB, Whitworth T, Bouyer DH, McBride J, Camargo LMA, Camargo EP, et al. Rickettsia bellii and Rickettsia amblyommii in Amblyomma Ticks from the State of Rondônia, Western Amazon, Brazil. J Med Entomol 2004; 41(6): 1073-1081. http://dx.doi. org/10.1603/0022-2585-41.6.1073

Labruna MB, Terassini FA, Camargo LM. First report of the male of Amblyomma rotundatum (Acari: Ixodidae) from a field-collected host. J Med Entomol 2005; 42(6): 945-947. http://dx.doi.org/10.1603/00222585(2005)042[0945:FROTMO]2.0.CO;2

Lainson R, Souza MC, Franco CM. Natural and experimental infection of the lizard Ameiva ameiva with Hemolivia stellata (Adeleina: Haemogregarinidae) on the toad Bufo marinus. Parasite 2007; 14(4): 323-328. PMid:18225421.

Lizaso NM. Fauna acarológica ectoparasita de serpentes não venenosas da região de construçáo de hidrelétricas (Sudeste, Centro-Oeste e Sul) do Brasil. Rev Bras Zool 1984; 2(2): 77-84.

Lopes SG, Andrade GC, Costa-Júnior LM. A first record of Amblyomma dissimile (Acari: Ixodidae) parasitizing the lizard Ameiva ameiva (Teidae) in Brazil. Rev Bras Parasitol Vet 2010; 19(4): 262-264. http://dx.doi. org/10.1590/S1984-29612010000400015

Martins TF, Onofrio VC, Barros-Battesti DM, Labruna MB. Nymphs of the genus Amblyomma (Acari: Ixodidae) of Brazil: descriptions, redescriptions, and identification key. Ticks Tick-borne Dis 2010; 1(2): 75-99. http://dx.doi.org/10.1016/j.ttbdis.2010.03.002

Martins JR, Monticelli EC, Onofrio VC, Barros-Battesti DM, Doyle RL. Primeiro relato de Amblyomma fuscum Neumann, 1907 (Acari: Ixodidae) parasitando lagarto da espécie Tupinambis teguixin (L.), no Município de Glorinha, Estado do Rio Grande do Sul, Brasil. Rev Bras Parasitol Vet 2007; 16(4): 246-247. PMid:18373904.

Oba MSP, Schumaker TTS. Estudo da biologia de Amblyomma rotundatum (Koch, 1844), em infestaçóes experimentais de Bufo marinus (L., 1758) sob condiçóes variadas de umidade relativa e de temperatura do ar. Mem Inst Butantan 1983-1984; 47-48(2): 195-204.

Onofrio VC. Revisão do gênero Amblyomma Koch, 1844 (Acari: Ixodidae) no Brasil [Tese]. Rio de Janeiro: Universidade Federal Rural do Rio de Janeiro; 2007. Available from: http://www.dominiopublico.gov.br/ pesquisa/DetalheObraForm.do?select_action=\&co_obra $=80113$.

Paperna I. Hemolivia mauritanica (Haemogregarinidae: Apicomplexa) infection in the tortoise Testudo graeca in the Near East with data on sporogonous development in the tick vector Hyalomna aegyptium. Parasite 2006; 13(4): 267-273. PMid:17285846.

Paperna I, Kremer-Mecabell T, Finkelman S. Hepatozoon kisrae n. sp. infecting the lizard Agama stellio is transmitted by the tick Hyalomma cf. aegyptium. Parasite 2002; 9(1): 17-27. PMid:11938691.

Petit G, Landau I, Baccam D, Lainson R. Description et cycle biologique d'Hemolivia stellata n. g., n. sp., hémogrégarine de crapauds brésiliensis. Ann Parasitol Hum Comp 1990; 65(1): 3-15.

Pontes JAL, Gazêta GS, Vrcibradic D, Rocha CFD. Ecology of ticks in a taxocenosis of snakes from the Serra do Mendanha, Rio de Janeiro, Brazil, with new host records. Zoologia 2009; 26(2): 328-333.

Prieto AS. Note on parasites of the tropical lizard Tropidurus hispidus. J Herpetol 1980; 14(2): 190-192. http://dx.doi.org/10.2307/1563856

Rodrigues DS, Maciel R, Cunha LM, Leite RC, Oliveira PR. Amblyomma rotundatum (Koch, 1844) (Acari: Ixodidae) two-host life-cycle on Viperidae snakes. Rev Bras Parasitol Vet 2010; 19(3): 174-178. http:// dx.doi.org/10.1590/S1984-29612010000300009

Sena MA, Silva JG, Nunes MS. Tropidurus torquatus (Calango, Collared Lizard). Herpetologic Rev 2008; 39(3): 369.

Siroký P, Mikulícek P, Jandzík D, Kami H, Mihalca AD, Rouag R, et al. Co-distribution pattern of a haemogregarine Hemolivia mauritanica (Apicomplexa: Haemogregarinidae) and its vector Hyalomma aegyptium (Metastigmata: Ixodidae). J Parasitol 2009; 95(3): 728-733. http://dx.doi. org/10.1645/GE-1842.1

Smallridge C, Paperna I. The tick-transmitted haemogregarinid of the Australian sleepy lizard Tiliqua rugosa belongs to the genus Hemolivia. Parasite 1997; 4(4): 359-363. 